\title{
The future of reference III: Discussion summary
}

\author{
By John Tongate \\ Head Librarian, Reference Services Department \\ The University of Texas at Austin
}

An audience discussion followed the panel presentations. Comments identified and developed three areas of interest: capability and extent of organizational change, acceptance by and effect of change on the individual, and the identification of opportunities for implementing change.

\section{Capability for and extent of change}

The opening audience observation was from the administrator's vantage point. The banquet of ideas presented by the speakers led to the need to focus on specifics. Thinking through the administrative responsibility for change is an ongoing problem of getting programs started while overcoming inertia and making already established programs stop. Persuasion is necessary to start the new paradigm. There will be dislocation, and a focus on pragmatism is needed. We are moving toward a more electronic library, but what does electronic library mean-information paradise? The movement toward an information paradise is a frightening concept for some users and staff, and the vision is difficult to deal with. An academic research library may never be a total electronic library, although a substantial part may be. We must begin with and pursue visions as plans change. We must focus on why libraries exist as we work through new paradigms, but it is necessary to keep ties with the past. As we develop electronic libraries they must be friendly and grounded in traditional values.

\section{Effect on the individual}

A member of the audience noted that it has been observed that it takes a generation for new technology to be accepted. Does this apply today? When using new technology, will people become insular and will they change psychologically to the extent that they will not communicate in person with librarians or other humans? A panelist responded that developing technology won't obviate human contact. Many have seen the simulated "knowledge navigator," the concept of John Scully, CEO of Apple Computer, on video. The ambience in the closing scene is one of comfort, as in a living room. There is only one human. But on the computer screen there is the face of an individual which is personal. The scholar is not isolated in a room or a box. In addition to accessing published literature, there is the option of calling someone on a network and talking with an image on a screen. How do we get the computer to this point of responsiveness? The original EDUCOM audience viewing the concept was very excited, a critical step in getting an operational system as demonstrated.

Technology no longer moves with generations. Consider the acceptance of flight. We have to look at how we will mold and not be molded by technology; what will it do for us and to us? We are the dominating factor. No one can know what will happen, but we should be proactive. It is better to think and make change happen rather than sit back, wait, and react.

A member of the audience questioned what is the model that people expect the computer to accomplish. Expert systems and artificial intelligence are thought to be something amazing. What model is driving them? A boy sees his father as a hero, yet later as a human being. Superman and Flash Gordon were heroes who had answers. Are expert systems and artificial intelligence today's super daddy? Is what we really want God in a box? Machines which parallel human intelligence won't help us a lot. A servant all-powerful seems to be the model. A Wizard of Oz image is envisioned where curtains part and all information is revealed.

A panelist responded, "Are systems a phase in evolutionary development, subject to the vagaries of the natural world?" We lurch forward in an Orwellian environment of budget deficits and rapid developments in eastern Europe. We advance as the Third World regresses, raising the questions of how developing systems will dislocate us further from other societies that cannot create or even look at the Scully image. We must give more than lip service to such situations and we must be cautious of how and where we are going.

\section{Implementing change}

Another panelist noted that the medical field may be a model of where we are going. Perfection of the human body is being attempted, for example, 
by gene splicing. Are we creating artificial intelligence as a perfect system? We are not modeling on any one thing, rather we are attempting multiple experts in one system. As in medicine, we are trying to create the same environment of perfection in information systems.

A third panelist offered a different perspective. Can we anticipate user acceptance based on practical experience? Users in reference departments refuse to use paper indexes in deference to a computer index. A computer version is seen as better, even if only tangentially related to the subject pursued. On the other hand, paper can be seen as authoritative. A photocopy looks more like the real thing. A list of citations is okay, but an article on a computer screen is questioned. What is the authority behind the article? It could have been dumped into a word processing package and changed. Faculty question the source of data from a computer. A panelist noted that the Society for Scholarly Publishing is interested in related issues of the online environment. How do you bind online information together so that it cannot be cut and pasted, thus avoiding false information?

Final observations came from two panelists. Consider the present academic environment and the turnover of faculty as older members retire. This is an opportunity to look at doing things differently with new, younger faculty members. Be aggressive in forming expectations of new faculty and building a new future with them. There may be a problem of a gap in the generational development. A "lost generation" of the 1970s was driven out of Ph.D. programs, especially in the social sciences and humanities. The present new generation has been trained by remaining faculty 30 to 40 years older. New Ph.D.'s have come out with the same old habits learned from the same old faculty.

The intrigued audience was very interested in the ideas and speculations of the presentations and discussion, having already been exposed to changes made as the paradigm has begun to shift in their own work environments. Some ideas discussed are still untested, but the audience drew upon experience to relate them to reality, evaluating the new ideas accordingly. After devoting an hour and a half to considering and discussing both the theoretical and practical aspects of new structures of service in an electronic environment, participants left the program with renewed enthusiasm for involvement in ongoing growth and change.

\section{New Jersey media assessment available}

The A-V Committee of the New Jersey Library Association; College and University Section, has just published the results of a survey of academic media collections and services in New Jersey. The survey is thought to be one of the most extensive surveys of state media ever completed. It was done to encourage the exchange of information at a time of proliferating technologies, skyrocketing expenses, and budget cutbacks. It includes inventories of hardware and software, circulation statistics by format, services offered, media production figures, teleconferencing and satellite information, media personnel information, and information about borrowing and lending.

While not all schools in New Jersey responded to the survey, major institutions (e.g., Drew, Montclair, NJIT, Princeton, Rutgers, Seton Hall, and Trenton State) did. Also included is a directory of academic media contacts in the state.

Copies of the 47-page publication are available from the New Jersey Library Association, P.O. Box 1534, Trenton, NJ 08607. Include a check payable to the New Jersey Library Association for $\$ 3.25$ to cover printing and mailing costs.

\section{$C \mho R L$ News acting editor appointed}

Sandra Naiman began as the $C \& R L$ News acting editor on October 8, 1990. Naiman has an MLS from Rosary College and a Ph.D in English from the University of Arkansas. She has taught English and journalism at Northern Illinois University and served as a subject specialist in literature at the Northern Illinois University Library.

Naiman replaces George Eberhart who resigned after editing $C \& R L$ News for ten years.
The search for the new editor of $C \mho R L$ News has begun and applications are due November 15, 1990. For further information call the ALA Human Services Department, (800) 545-2433 x2466. Naiman can be reached at x3248. 